\title{
A Methylene-Bridged Titanium-Aluminium Complex for Olefinations of Carbonyls: The Tebbe Reagent
}

\section{Key words}

titanium

aluminum

olefination

methylene transfer

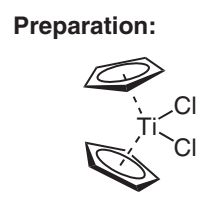

(1.0 equiv)

Selected reactions:<smiles>O=C1CCCCC1</smiles>

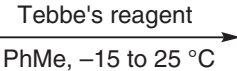<smiles>O=C(c1ccccc1)c1ccccc1</smiles>

Tebbe's reagent

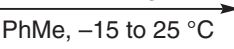<smiles>CCOC(C)=O</smiles>
$\underset{\text { PhMe, }-15 \text { to } 25^{\circ} \mathrm{C}}{\stackrel{\text { Tebbe's reagent }}{\longrightarrow}}$<smiles>O=Cc1ccccc1</smiles>

$\underset{\text { PhMe },-15 \text { to } 25^{\circ} \mathrm{C}}{\stackrel{\text { Tebbe's reagent }}{\longrightarrow}}$<smiles>[3H]C([3H])=O</smiles>

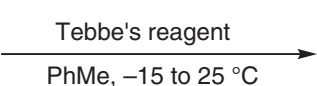

4 examples $\underset{\mathrm{PhMe}, 25^{\circ} \mathrm{C}, 60 \mathrm{~h}}{\mathrm{AlMe}_{3}(2.0 \text { equiv) }}$

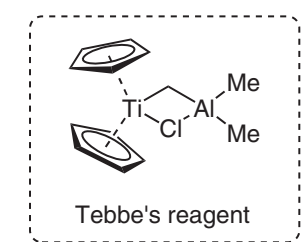

Significance: In 1978, Frederick N. Tebbe, George W. Parshall, and G. S. Reddy published a procedure for the generation of methylene-bridged compounds of the general structure $\mathrm{Cp}_{2} \mathrm{Ti}-\mathrm{CH}_{2} \mathrm{AIXR}_{2}$ and their application in insertion reactions into alkenes and olefinations of carbonyl compounds. The authors conducted mechanistic studies, using $\mathrm{Cp}_{2} \mathrm{Ti}-\mathrm{CH}_{2} \mathrm{AICl}\left(\mathrm{CD}_{3}\right)_{2}$. When performing olefination reactions with the deuterated Tebbe reagent and cyclohexanone, no deuterium was observed in the resulting olefin product, indicating that solely the bridging methylene group is transferred. Generating similar reagents using $\mathrm{ZnMe}_{2}$ instead of $\mathrm{AlMe}_{3}$ was also possible, and those showed similar reactivities in olefination reactions.
Comment: Active species in the reaction is most likely not the Tebbe Reagent itself but a bis $\left(\eta^{5}\right.$ cyclopentadienyl)-(methylene)titanium(IV), which is generated by treatment of the Tebbe Reagent with a Lewis base. The mechanism is likely to proceed via [2+2] cycloaddition, forming an oxatitanacyclobutane, which fragments irreversibly into the olefin product and titanocene oxide. The procedure allows for instance the methenylation of aldehydes, ketones, esters, amides, and carbonates. Alternatively, the Petasis reagent (V. Am. Chem. Soc. 1990, $112,6392)$ can be obtained by treatment of $\mathrm{Cp}_{2} \mathrm{Ti}$ $\mathrm{Cl}_{2}$ with methyl Grignard or methyllithium. Petasis reagent reacts upon heating with the mentioned carbonyl compounds and in addition allows olefination of acid anhydrides. Furthermore, the reaction conditions are milder since no basic conditions and no Lewis acids are needed. 